\title{
The Roles of Matricellular Proteins in Oncogenic Virus-Induced Cancers and Their Potential Utilities as Therapeutic Targets
}

\author{
Naoyoshi Maeda ${ }^{1, *}$ and Katsumi Maenaka ${ }^{1,2}$ \\ 1 Center for Research and Education on Drug Discovery, Faculty of Pharmaceutical Sciences, \\ Hokkaido University, Kita-12, Nishi-6, Kita-ku, Sapporo 060-0812, Japan \\ 2 Laboratory of Biomolecular Science, Faculty of Pharmaceutical Sciences, Hokkaido University, \\ Kita-12, Nishi-6, Kita-ku, Sapporo 060-0812, Japan; maenaka@pharm.hokudai.ac.jp \\ * Correspondence: nmaeda@pharm.hokudai.ac.jp; Tel.: +81-11-706-3773
}

Received: 6 September 2017; Accepted: 18 October 2017; Published: 21 October 2017

\begin{abstract}
Matricellular proteins differ from other classical extracellular matrix proteins; for instance, they are transiently expressed as soluble proteins rather than being constitutively expressed in pathological conditions, such as acute viral infections. Accumulating studies have revealed that matricellular proteins, including osteopontin and tenascin-C, both of which interact with integrin heterodimers, are involved in inflammatory diseases, autoimmune disorders, and cancers. The concentrations of these matricellular proteins are elevated in the plasma of patients with certain types of cancers, indicating that they play important roles in oncogenesis. Chronic viral infections are associated with certain cancers, which are distinct from non-viral cancers. Viral oncogenes play critical roles in the development and progression of such cancers. It is vital to investigate the mechanisms of tumorigenesis and, particularly, the mechanism by which viral proteins induce tumor progression. Viral proteins have been shown to influence not only the viral-infected cancer cells, but also the stromal cells and matricellular proteins that constitute the extracellular matrix that surrounds tumor tissues. In this review, we summarize the recent progress on the involvement of matricellular proteins in oncogenic virus-induced cancers to elucidate the mechanism of oncogenesis and consider the possible role of matricellular proteins as therapeutic targets in virus-induced cancers.
\end{abstract}

Keywords: matricellular proteins; oncogenic viruses; osteopontin (OPN); periostin (POSTN); secreted protein acidic and rich in cysteine (SPARC); tenascin-C (TNC); thrombospondin (TSP); tumor microenvironment

\section{Introduction}

Matricellular proteins exhibit different phenotypes to those of the classical extracellular matrix (ECM) proteins in vivo; for instance, they induce cell motility rather than providing scaffolds for stable cell adhesion [1]. In addition, they are transiently expressed as soluble proteins during embryogenesis and organogenesis and in pathological conditions rather than being constitutively expressed [1]. Interestingly, an elevated expression of these molecules has been described in various inflammatory diseases; for instance, acute viral infections are known to induce the expression of certain matricellular proteins, such as osteopontin [2]. Moreover, an altered expression of the matricellular proteins has also been detected in patients with cancers, suggesting the involvement of these molecules in tumorigenesis. It is well-known that chronic virus infections frequently cause tumors. So far, seven human tumor viruses have been identified, namely, Epstein-Barr virus (EBV), hepatitis B virus (HBV), hepatitis C virus (HCV), human papillomavirus (HPV), human T-cell leukemia virus type I (HTLV-I), and Kaposi's sarcoma-associated herpesvirus (KSHV), and the recently characterized 
Merkel cell polyomavirus (MCPyV). These viruses are the etiological agents for nasopharyngeal carcinoma, HBV-related hepatocellular carcinoma (HCC), HCV-related HCC, cervical cancer, adult T-cell leukemia (ATL), Kaposi's sarcoma (KS)/primary effusion lymphoma (PEL), and Merkel cell carcinoma (MCC), respectively [3]. Research on these virus-induced cancers has focused on the viruses or tumor antigens/tumor-derived molecules. However, it remains unclear how the host stromal cells and the matricellular proteins constituting the ECM in the tumor microenvironment are involved in the development and progression of such virus-induced cancers. Here, we focus on the involvement of the matricellular proteins in virus-induced cancers and their associations with viral oncogenes. Furthermore, we discuss the potential utilities of the matricellular proteins as therapeutic targets in virus-induced cancers. To the best of our knowledge, this is the first systematic review to describe the relationships between oncogenic human virus-induced cancers and matricellular proteins.

\section{Current Knowledge Regarding the Roles of the Matricellular Proteins That Constitute the ECM} in the Tumor Microenvironment

\subsection{Osteopontin (OPN)}

OPN is a phosphorylated glycoprotein that is produced by several types of cells such as osteoclasts, endothelial cells, epithelial cells, and immune cells to play a major role in normal physiological processes, including bone remodeling, vascularization, and immune regulation [4]. OPN was initially named "secreted phosphoprotein 1" because it was observed to be secreted from mammalian cells that had been transformed with tumor-promoting viruses [5]. Further studies have revealed that OPN contains several variants that are encoded by alternative splicing, and the expression of each of the variants correlates with specific types of cancer [6]. OPN interacts with integrins. The integrins consist of $18 \alpha$-subunits and $8 \beta$-subunits, and they form heterodimers consisting of an $\alpha$-subunit and a $\beta$-subunit, which act as functional receptors [7]. Within OPN, the $\alpha \mathrm{v} \beta 1, \alpha \mathrm{v} \beta 3, \alpha \mathrm{v} \beta 5, \alpha 5 \beta 1$, and $\alpha 8 \beta 1$ integrins bind to the RGD motif, while the $\alpha 9 \beta 1, \alpha 4 \beta 1$, and $\alpha 4 \beta 7$ integrins bind to the SVVYGLR motif (Figure 1) [1]. OPN also binds to CD44 splice variants, such as CD44v3, CD44v6, and CD44v7, via its C-terminus fragment, including calcium-binding domain (Figure 1) [8]. Many papers have described the roles of OPN binding to integrins and CD44 in inflammatory disorders, autoimmune diseases, and tumorigenesis [4]. OPN production is elevated in various disorders; thus, it can be a useful biomarker [9]. In addition, an elevated level of anti-OPN autoantibodies has been observed in some cases $[10,11]$. OPN may be an attractive target for cancer therapy, and anti-OPN monoclonal antibodies (mAbs) have been evaluated in clinical models of various disorders [12-15].

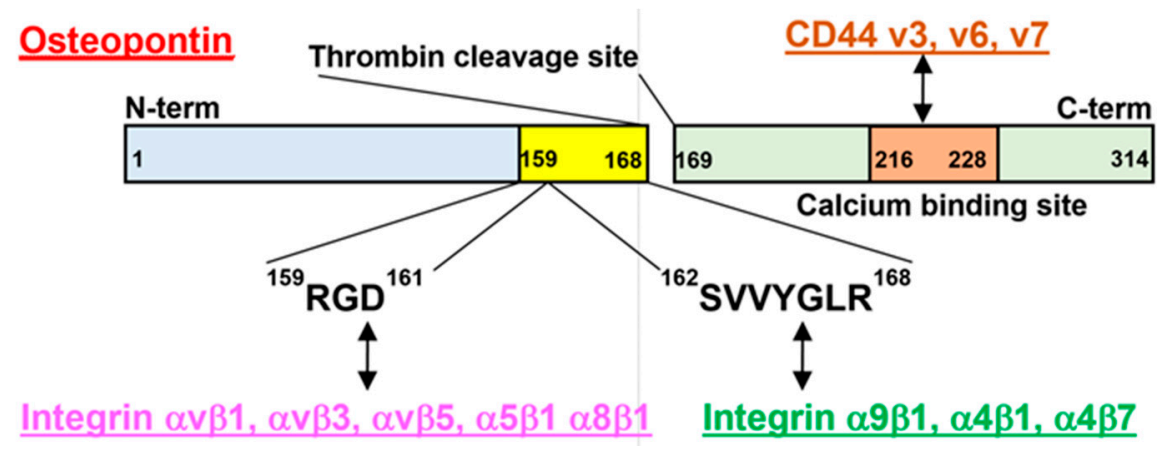

Figure 1. Structure of osteopontin (OPN). Amino acid (a.a.) sequences/domains involved in the receptor binding are shown. The $\alpha \mathrm{v} \beta 1, \alpha \mathrm{v} \beta 3, \alpha \mathrm{v} \beta 5, \alpha 5 \beta 1$, and $\alpha 8 \beta 1$ integrins bind to the RGD (159-161 a.a.) motif, while the $\alpha 9 \beta 1, \alpha 4 \beta 1$, and $\alpha 4 \beta 7$ integrins bind to the SVVYGLR (162-168 a.a.) motif of OPN. The CD44v3, v6, and v7 bind to the OPN via its C-terminus fragment (169-300 a.a.) including calcium binding site (216-228 a.a.). 


\subsection{Tenascin-C (TNC)}

The tenascin family consists of 4 genes encoding TNC, tenascin- $\mathrm{R}$, tenascin- $\mathrm{X}$, and tenascin- $\mathrm{W}$, which share biological functions in the ECM [16]. Among them, TNC is particularly interesting. TNC is a hexameric glycoprotein that consists of epidermal growth factor-like repeats, fibronectin-type 3 repeats, and a fibrinogen-related domain [17]. Through each of its domains, TNC physiologically interacts with the $\alpha v \beta 1, \alpha v \beta 3, \alpha v \beta 6, \alpha 2 \beta 1, \alpha 7 \beta 1, \alpha 8 \beta 1$, and $\alpha 9 \beta 1$ integrins [18] and plays roles in cell motility, survival and proliferation [19]. TNC has been shown to not only regulate embryogenesis but also to be transiently expressed during inflammation or pathological responses as well as repair processes after tissue injury [20]. TNC expression is detected in stromal cells, such as fibroblasts and epithelial cells [21]. In addition, TNC is highly expressed in cancer tissues [21]. An increased concentration of TNC in plasma or serum has been detected in patients with various disorders, including cancers; thus, the expression of TNC may be a biological marker for certain diseases [22-24]. In addition, an elevated level of anti-TNC antibodies has been observed in some cases [25]. TNC could be an attractive target for the therapy of certain diseases, and the antigen-binding or single-chain $\mathrm{Fv}$ fragments derived from anti-TNC mAbs have been evaluated in heart diseases [26,27].

\subsection{Thrombospondin (TSP)}

TSP consists of the subgroup A proteins TSP-1 and -2, which form homotrimers, and the subgroup B proteins TSP-3, -4 , and -5 , which form homopentamers [28]. Among the TSP proteins, TSP-1 was initially isolated from human platelets as an inhibitor of angiogenesis [29]. TSP-1 consists of an $\mathrm{N}$-terminal heparin-binding domain, the procollagen domain, types 1-3 repeated sequence motif regions, and the globular C-terminal domain. TSP- 1 binds to the $\alpha \mathrm{v} \beta 3, \alpha \operatorname{IIb} \beta 3, \alpha 3 \beta 1, \alpha 4 \beta 1$, and $\alpha 5 \beta 1$ integrins to exert the functions of cell adhesion and migration [30]. Furthermore, it interacts with CD36 and CD47 via its type 1 central repeats and C-terminal domain, respectively; these interactions have been well studied in the regulation of angiogenesis, in which TSP-1 antagonizes the effect of the proangiogenic nitric oxide signaling pathway on endothelial cells [31]. Reduced levels of TSP-1 may be a predictor of cancer and angiogenesis-associated disease progression [32-34]. Thus, blocking the interaction of vascular endothelial growth factor (VEGF) with its receptor by TSP-1 mimetic during angiogenesis could be a potential approach for cancer therapy [35]. Indeed, TSP-1 peptide mimetic covalently linked to a humanized antibody have been evaluated in pre-clinical and clinical trials [36,37].

\subsection{Periostin (POSTN)}

POSTN (also known as osteoblast-specific factor 2) was originally found in osteoblasts [38]; thus, it plays a critical role in the maintenance and development of bone tissues [39]. POSTN is composed of a cysteine-rich region and a four-coiled fasciclin-like repeats region [40]. In addition to interacting with the matricellular proteins described above, POSTN also interacts with the $\alpha v \beta 3$, $\alpha v \beta 5$ and $\alpha 6 \beta 4$ integrins to promote the invasion of tumor cells [41,42]. In addition, POSTN is known to activate the canonical wingless-related integration site (Wnt) signaling pathways, which are involved in cancer stem cell maintenance [43]. Related to this role in the regulation of Wnt signaling, POSTN has been identified as an epithelial-mesenchymal transition (EMT) marker [44]. Thus, these two independent interaction-induced signaling pathways are important for the development and maintenance of cancer cells [40]. Elevated levels of POSTN have been detected in sera from patients with various types of cancers [45-47], suggesting that POSTN may be a useful biomarker for those cancers. The detection of POSTN by the immunohistochemical (IHC) staining of tumor lesions by anti-POSTN mAbs targeting the fasciclin domain, which can inhibit integrin-mediated cell migration in vitro, has also been reported [48]. In a breast tumor model in vivo, the administration of anti-POSTN neutralizing antibodies inhibited the proliferation, migration, and invasion of breast tumor cells, as well as the differentiation of osteoclasts [49]. 


\subsection{Secreted Protein Acidic and Rich in Cysteine (SPARC)}

SPARC (also known as osteonectin and basement membrane 40) is a secreted glycoprotein that was initially identified as a bone-specific protein showing selective binding to collagen and hydroxyapatite [50]. SPARC consists of three functional domains including an N-terminus acidic domain, a follistatin-like domain, and a C-terminus domain [51]. Cell type secreting SPARC include endothelial cells, fibroblasts, pericytes, astrocytes, osteoblasts, and macrophages in regulating several physiological processes, including development, tissue remodeling, and wound repair [52]. SPARC is also involved in the development of fibrosis in various disorders including hypertension, diabetes, and liver cirrhosis [52]. In an in vivo model using SPARC-deficient mice, SPARC exhibited a tumor suppressor function modulating carcinogenesis, progression, and metastasis [53]. Interestingly, however, the overexpression of SPARC was observed in certain types of tumors [54]; thus, it may act as an indicator of tumor progression [55]. The IHC staining of prostate cancer samples showed the presence of SPARC protein in the epithelial tumoral cells of metastatic cases, indicating that it may promote the invasion and metastasis of cancer cells [56]. In lung cancer, transforming growth factor (TGF)- $\beta 1$-induced extracellular signal-regulated kinase (ERK) signaling enhanced the expression of SPARC mRNA [57]. Correspondingly, SPARC expression in tumor cells correlated with EMT features, and the expansion and infiltration of myeloid-derived suppressor cells, which contribute to tumor growth and dissemination, was indirectly regulated by SPARC, as well as OPN [58].

\section{The Involvement of Matricellular Proteins in the Tumorigenesis of Oncogenic Virus-Induced Cancers and Their Potential Utilities as Therapeutic Targets}

So far, seven viruses have been well characterized as the causative agents of specific human cancers [3]. Although numerous papers have reported on the mechanisms of the tumorigenesis of oncogenic virus-induced cancers, it remains unclear whether and how the matricellular proteins are involved in the tumorigenesis of those cancers. In this section, we summarize the reports describing the expression and production of matricellular proteins in the oncogenic virus-induced cancers. In Sections 3.2-3.7 we discuss the reports describing only virus-infection-related cancer cases, excluding non-viral-related cases and those in which the presence of a viral infection was unclear.

\subsection{HTLV-I-Induced ATL}

HTLV-I is classified in the Retroviridae family; the HTLV-I genome comprises approximately $9 \mathrm{~kb}$ of single-stranded RNA encoding three structural genes ( $\mathrm{g} a g$, pol, and env) and several alternatively-spliced regulatory genes [59]. HTLV-I has been identified as a causative agent of ATL, which is a CD4 ${ }^{+}$T-cell malignancy [60]. Recent studies have revealed the genetic and epigenetic changes that are involved in ATL tumorigenesis [61,62]. The viral factors involved in ATL oncogenesis are Tax and HBZ [59]. The expression of OPN was partially induced by the HTLV-I Tax protein [63]. However, the expression of OPN in ATL cell lines and HTLV-I-infected T cell lines is low [64]. The IHC staining of tissues from ATL patients revealed the expression of OPN in both tumors and stromal cells such as macrophages and endothelial cells $[64,65]$. Furthermore, in the plasma of ATL patients, the OPN levels detected by enzyme-linked immunosorbent assay (ELISA) were elevated and showed a correlation with the disease severity, suggesting that OPN is critically involved in the development of ATL [65]. In the NOD/Shi-scid,IL-2Rgnull (NOG) mouse model transplanted with ATL cells, the expression of host stromal cell-derived OPN increased during the progression of the disease, indicating that the stromal OPN may support the tumorigenesis of ATL (Figure 2) [64].

The mechanism of elevated OPN expression from the host cells is not yet clear. It is intriguing that OPN production can be detected in the fibroblasts of ATL patients [64] and the co-cultivation of ATL cells with mouse embryo-derived fibroblasts enhanced their OPN production in vitro. Thus, the molecular mechanisms of OPN induction by viral factor $X(\mathrm{~s})$ are currently being investigated (Figure 2). Considering the potential therapeutic aspect, anti-OPN mAbs exhibited suppressive effects on ATL tumor growth and metastasis by suppressing OPN expression in cancer-associated 
fibroblasts [64]. In addition, OPN is known to induce VEGF via the activation of phosphoinositide 3-kinase (PI3K)/protein kinase B (Akt) and ERK1/2 signaling in endothelial cells [66], and it promotes VEGF-dependent breast tumor growth and angiogenesis [67]. Thus, the elevated expression of OPN in ATL may be involved in angiogenesis. At least two reports have indicated that VEGF is a critical factor for the progression of ATL [68,69]. However, the expression of VEGF is Tax-independent [70], suggesting that the role of OPN-induced VEGF expression in the tumorigenesis of ATL warrants further investigation. As mentioned in Section 2.5, SPARC exhibited a tumor suppressor effect [51]. Interestingly, the use of RNA interference to suppress the expression of SPARC enhanced the apoptotic effects of bortezomib on ATL cells by increasing cleaved caspase 3 expression, suggesting that SPARC could be another therapeutic target for ATL (Table 1) [71].

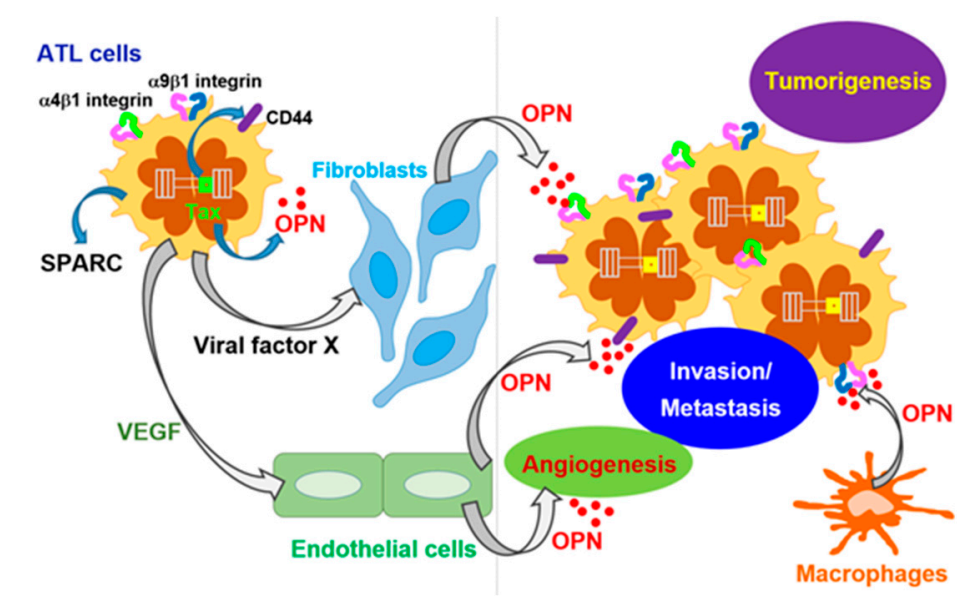

Figure 2. Proposed mechanisms of adult T-cell leukemia (ATL) tumorigenesis and metastasis.

Table 1. Association of viral genes/oncogenes with the matricellular proteins.

\begin{tabular}{|c|c|c|c|c|}
\hline Viruses & $\begin{array}{l}\text { Viral Genes/ } \\
\text { Oncogenes }\end{array}$ & $\begin{array}{c}\text { Matricellular } \\
\text { Proteins }\end{array}$ & Phenomena/Mechanisms & References \\
\hline \multirow[t]{3}{*}{ HTLV-I } & Tax & OPN & Transcriptional upregulation of OPN resulted in the activation of PI3K/Akt pathway & [63] \\
\hline & $?$ & OPN & Stromal cell-derived OPN involved in the tumorigenesis and metastasis & {$[64,65]$} \\
\hline & ? & SPARC & SPARC inhibition resulted in caspase 3-dependent apoptosis by bortezomib & [71] \\
\hline \multirow[t]{3}{*}{ HBV } & HBx & OPN & 5-LOX-dependent upregulation of OPN promoted cell migration & {$[74,75]$} \\
\hline & $?$ & OPN & Elevated production in cirrhosis and HCC & [76-78] \\
\hline & $?$ & TSP-1 & Elevated production in fibrosis & [80] \\
\hline \multirow[t]{3}{*}{$\mathrm{HCV}$} & NS3/4A, NS5A & TSP-1 & Proteolytic activation of TGF- $\beta$ by intracellular TSP- 1 & [83] \\
\hline & Core & TSP-1 & Increased secretion of TSP-1 activated TGF- $\beta$ & [84] \\
\hline & $?$ & OPN & Antisense ODNs suppressed lung metastasis via downregulating MMP-2 and uPA & [92] \\
\hline \multirow[t]{3}{*}{ HPV } & E6, E7 & TSP-1 & Decreased expression in keratinocytes & [96-98] \\
\hline & $?$ & OPN & Induction of furin via p38 and NF-kB resulted in cancer progression & [99] \\
\hline & $?$ & Tenascin * & Expressed during the premalignant stage & [103] \\
\hline \multirow[t]{2}{*}{ EBV } & $?$ & OPN & Elevated expression & [107] \\
\hline & LMP1, EBER & $\begin{array}{l}\text { SPARC } \\
\text { POSTN }\end{array}$ & Elevated expression & {$[107,108]$} \\
\hline \multirow[t]{3}{*}{ KSHV } & ? & Tenascin * & Expressed in the vessel walls & [112] \\
\hline & $?$ & TSP-1 & Viral miRNA-dependent TSP- 1 reduction decreased TGF- $\beta$ activity & {$[113,114]$} \\
\hline & $?$ & OPN & Viral miRNA-dependent reduction & [114] \\
\hline $\mathrm{MCPyV}$ & sT antigen? & TNC & Tumorigenesis and metastasis & {$[118,119]$} \\
\hline
\end{tabular}

\subsection{HBV-Related HCC}

HBV is a member of the Hepadnaviridae family. The HBV genome comprises approximately $3.2 \mathrm{~kb}$ of double-stranded DNA encoding seven proteins and four regulatory elements [72]. While the mechanism of HCC tumorigenesis by HBV has been thought to be caused by an immune response leading to chronic inflammation, the $\mathrm{HBV} x$ protein $(\mathrm{HBx})$ has also been considered to be involved in 
HCC tumorigenesis [73]. The HBx can upregulate the expression of OPN via 5-lipoxygenase (5-LOX) in vitro (Table 1) [74,75]. The concentration of OPN in the blood plasma is predictive of cirrhosis in patients with HBV infection [76,77]. IHC staining also confirmed the relationship between OPN and HBV-related HCC [78], suggesting that OPN is involved in several steps during the development of HCC in the HBV-infected liver. The administration of OPN during the immune response against HBV improved the maturation and function of dendritic cells, suggesting the possibility of using immunotherapy for HCC [79]. A recent study identified that TSP-1 was upregulated in the sera of patients with hepatic fibrosis by an unknown mechanism (Table 1) [80].

\subsection{HCV-Related HCC}

$\mathrm{HCV}$ is classified in the Flaviviridae family. The HCV genome comprises approximately $9.6 \mathrm{~kb}$ of single-stranded positive sense RNA encoding three structural proteins and seven non-structural proteins [81]. The HCV genes encoding proteins with oncogenic potential are not identified. Thus, similar to HCC tumorigenesis induced by HBV, that induced by HCV has been also considered to result from an immune response followed by chronic inflammation [82]. In HCV-infected cells, two nonstructural proteins encoded by HCV, namely NS3/4A and NS5A, played critical roles in the induction and secretion of TGF- $\beta 1$ (Table 1) [83]. HCV induces the intracellular expression of TSP-1, which is involved in the proteolytic activation of TGF- $\beta 1$ [83]. The HCV core protein was also reported to mediate the activation of TGF- $\beta$ via TSP-1 (Table 1) [84]. TGF- $\beta$ signaling can induce EMT- and tumor-initiating cancer stem-like cells in hepatocytes [85-87]; thus, such HCV core protein-induced TSP-1-mediated TGF- $\beta 1$ activation is a critical event in HCC tumorigenesis. Serum or plasma OPN could be a biomarker for hepatic fibrosis or inflammation in patients infected with HCV [88-91]. Therefore, OPN is a biomarker for HCC development. Antisense oligodeoxynucleotides (ODNs) suppressing the expression of OPN inhibited the migration and invasion of an HCC cell line in vitro. Furthermore, when nude mice were transplanted with the same HCC cell line in vivo, the antisense ODNs targeting the tumor-derived expression of OPN significantly suppressed lung metastasis via downregulating matrix metalloproteinase (MMP)-2 and urokinase-type plasminogen activator (uPA) (Table 1) [92]. These findings suggest that OPN is a therapeutic target for suppressing the metastasis of HCC. The molecular mechanism of HCV-induced OPN processing involves the increased phosphorylation and activation of p38, c-Jun N-terminal kinase, phosphatidylinositol 3-kinase, and mitogen-activated protein kinase kinase 1/2 [93].

\subsection{HPV-Induced Cervical Cancer}

HPV is classified in the Papillomaviridae family. The HPV genome comprises approximately $8 \mathrm{~kb}$ of double-stranded DNA, which encodes six early genes and two late genes [94]. The HPV genes encoding the E6 and E7 proteins have been considered as oncogenes involved in the tumorigenesis of cervical cancer [95]. The experimental expression of the E6 and E7 proteins of HPV-16 increased the expression of VEGF/interleukin-8 and decreased that of TSP-1 in keratinocytes (Table 1) [96-98], suggesting that those HPV proteins are involved in angiogenesis. Bao et al. reported that OPN was highly detected in HPV-positive patients with cervical cancer, suggesting that OPN could be involved in the HPV-associated progression of cervical cancer [99]. However, that study did not describe any relationship between the HPV proteins and the enhanced OPN expression in HPV-positive lesions. The HPV minor capsid protein L2 is cleaved by furin, which is a cellularly-encoded proprotein convertase that is required for endosome escape [100]. OPN was reported to induce the expression of furin via p38 and nuclear factor $\mathrm{kB}$ signaling and thereby support the progression of cervical cancer [101], suggesting that the OPN-furin axis is involved in not only the viral entry step but also the pathogenesis of cervical cancers (Table 1). Enhanced Tenascin expression was detected in cervical and vulvar koilocytotic lesions [102]. In addition, Tenascin mRNA was detected in cervical lesions and its expression level strongly correlated with the degree of inflammation but not that of dysplasia, indicating that tenascin could be a marker of the premalignant stage of cervical cancer (Table 1) [103]. 
The infected cells undergo a process of differentiation during the viral life cycle. Thus, achieving a fuller understanding the interactions between the infected cells and the stromal cells in the tumor microenvironment should be regarded as a critical goal [104].

\subsection{EBV-Related Nasopharyngeal Carcinoma}

EBV (also known as human herpesvirus 4) is classified in the Herpesviridae family. The EBV genome comprises approximately $170 \mathrm{~kb}$ of double-stranded DNA [105]. It is the first human tumor virus that was reported to be involved in Burkitt lymphoma, which is an aggressive B-cell malignancy, and it has been also identified as a causative agent for nasopharyngeal carcinoma [106]. A gene expression profiling analysis confirmed the elevated expression of OPN and SPARC in EBV-infected gastric adenocarcinoma (Table 1) [107]. The expression of SPARC and POSTN was found to be upregulated in nasopharyngeal carcinoma stem cells and showed a correlation with the expression of EBV genes such as EBV-encoded small RNA (EBER) and latent membrane protein 1 (LMP1) (Table 1) [108]. However, a role of these matricellular proteins in the pathogenesis of nasopharyngeal carcinoma remains to be elucidated.

\subsection{KSHV-Related KS and PEL}

KSHV (also known as human herpesvirus 8) is also classified in the Herpesviridae family. The KSHV genome comprises approximately $140 \mathrm{~kb}$ of double-stranded DNA [109]. KSHV infection is thought to be a causative factor of KS and PEL, in which the cells that give rise to the tumors are epithelial cells and B cells, respectively [110,111]. The IHC staining of KS lesions revealed that tenascin (of an unspecified subtype) was expressed in the vessel walls within, and outside, the spindle cell compartment, while TSP was expressed only by endothelial cells inside and outside the lesion, but not by the spindle cells (Table 1) [112]. TSP-1 has shown to inhibit VEGF signaling [31] and to suppress the induction of endothelial cell proliferation and motility by the conditioned supernatant of KS-like cells [113]. In a microarray analysis, the reduction of TSP-1 expression by a viral microRNA (miRNA) decreased the activity of TGF- $\beta$, which is a potent anti-inflammatory factor (Table 1) [114]. In PEL, the ceramide-induced upregulation of TSP-1 influenced the expression of multiple KSHV-related miRNAs and thereby led to cell cycle arrest [115]. Taken together, these observations collectively support the concept that TSP-1 regulates the angiogenic responses in KS lesions and PEL. In the microarray analysis, the expression of OPN was also decreased by the viral miRNA, although that study did not examine the involvement of OPN in angiogenesis and tumorigenesis [114].

\subsection{MCPyV-Induced MCC}

$\mathrm{MCPyV}$ has been recently identified as a causative agent of MCC, a neuroendocrine carcinoma of the skin [116]. The MCPyV genome comprises approximately $5.4 \mathrm{~kb}$ of double-stranded DNA, which is divided into three major regions: the non-coding regulatory region, the early coding region, and the late coding region [117]. A study performed IHC staining for TNC in MCC lesions and reported that TNC was expressed at metastatic areas and its abundance correlated with tumor size (Table 1) [118,119]. Although that study did not confirm the occurrence of MCPyV infection in the samples (since MCPyV had not yet been identified as a causative agent of MCC when that study was performed), their observations on the IHC staining of TNC are intriguing. Liu et al. reported that dermal fibroblasts are the natural host cells that support productive MCPyV infections ex vivo [120]. In the dermal fibroblasts, MMP gene expression and Wnt/ $\beta$-catenin signaling were induced by MCPyV infection. The MMPs are thought to play important roles in tumor invasion and metastasis; thus, an elevated expression of MMPs may contribute to the progression of MCC. MCPyV encodes the small T (sT) antigen, which is an oncogene that transforms rodent fibroblasts [121]. However, it is currently unclear whether any relationships between the sT antigen and matricellular proteins contribute to the tumorigenesis of MCC. 


\section{Conclusions}

The regulatory functions of matricellular proteins in the oncogenesis of virus-induced cancers and their potential utilities as therapeutic targets for such cancers has been summarized above. An altered abundance of certain matricellular proteins has frequently been detected in samples from patients with virus-induced cancers. The matricellular proteins are well evidenced to be involved in the tumorigenesis of such cancers, depending not only on the cell type, but also on the expression of viral oncogenes and their associated molecules in the cancer cells. However, based on this review of the recent reports, it seems that the potential involvement of the matricellular proteins in viral tumorigenesis has not been fully investigated. In particular, there is a lack of information regarding the involvement of the surrounding stromal cells and secreted matricellular proteins in the tumor microenvironment. Although the analysis of plasma or serum samples by ELISA is useful for determining the circulating concentrations of the matricellular proteins, this method cannot identify which cell type is the source of the proteins. Thus, the IHC staining of tumor lesions is more informative. Furthermore, a lack of suitable animal models for human oncogenic virus infections and the tumor development associated with those infections has hampered the progress of research on virus-induced cancers. Therefore, animal models that closely mimic the human virus-induced cancers need to be established. Based on our research on OPN and integrins in the ATL xenograft NOG mouse model [64], we believe that the involvement of matricellular proteins in human virus-induced cancers can be investigated by distinguishing between the tumor-derived human proteins and host stromal cell-derived murine proteins in vivo. Through our research, we have found that the interactions of tumor cells with host stromal cell-derived matricellular proteins are attractive as potential therapeutic targets. Thus, the development of mAbs and/or their genetically-engineered derivatives, such as their antigen-binding and single-chain Fv fragments targeting such interactions is encouraged [122]. Further investigations will be necessary to elucidate the clinical relevance and application of matricellular proteins in human oncogenic virus-induced cancers.

Acknowledgments: We sincerely thank Dr. Toshimitsu Uede, a professor emeritus of Hokkaido University, for supporting our research. This research is partially supported by the Platform Project for Supporting in Drug Discovery and Life Science Research (Platform for Drug Discovery, Informatics, and Structural Life Science) from the Ministry of Education, Culture, Sports, Science and Technology (MEXT), and Japan Agency for Medical Research and Development (AMED), and Hokkaido University, Global Facility Center (GFC), Pharma Science Open Unit (PSOU), funded by MEXT under "Support Program for Implementation of New Equipment Sharing System".

Author Contributions: Naoyoshi Maeda and Katsumi Maenaka wrote the paper.

Conflicts of Interest: The authors declare no conflicts of interest.

\section{Abbreviations}

$\begin{array}{ll}\text { a.a. } & \text { Amino acid } \\ \text { Akt } & \text { Protein kinase B } \\ \text { ATL } & \text { Adult T-cell leukemia } \\ \text { EBER } & \text { Epstein-Barr virus-encoded small RNA } \\ \text { EBV } & \text { Epstein-Barr virus } \\ \text { ECM } & \text { Extracellular matrix } \\ \text { ELISA } & \text { Enzyme-linked immunosorbent assay } \\ \text { EMT } & \text { Epithelial-mesenchymal transition } \\ \text { ERK } & \text { Extracellular signal-regulated kinase } \\ \text { HBV } & \text { Hepatitis B virus } \\ \text { HBx } & \text { Hepatitis B virus x protein } \\ \text { HCC } & \text { Hepatocellular carcinoma } \\ \text { HCV } & \text { Hepatitis C virus } \\ \text { HHV } & \text { Human herpesvirus } \\ \text { HPV } & \text { Human papillomavirus } \\ \text { HTLV-I } & \text { Human T-cell leukemia virus type I } \\ \text { IHC } & \text { Immunohistochemical }\end{array}$




$\begin{array}{ll}\text { KS } & \text { Kaposi's sarcoma } \\ \text { KSHV } & \text { Kaposi's sarcoma-associated herpesvirus } \\ \text { LMP1 } & \text { Latent membrane protein 1 } \\ \text { LOX } & \text { Lipoxygenase } \\ \text { mAb } & \text { Monoclonal antibody } \\ \text { MCPyV } & \text { Merkel cell polyomavirus } \\ \text { MCC } & \text { Merkel cell carcinoma } \\ \text { MEK } & \text { Mitogen-activated protein kinase kinase } \\ \text { miRNA } & \text { MicroRNA } \\ \text { MMP } & \text { Matrix metalloproteinase } \\ \text { NOG } & \text { NOD/Shi- scid,IL-2Rg }{ }^{\text {null }} \\ \text { ODN } & \text { Oligodeoxynucleotide } \\ \text { OPN } & \text { Osteopontin } \\ \text { PEL } & \text { Primary effusion lymphoma } \\ \text { PI3K } & \text { Phosphoinositide 3-kinase } \\ \text { POSTN } & \text { Periostin } \\ \text { SPARC } & \text { Secreted protein acidic and rich in cysteine } \\ \text { ST } & \text { Small T } \\ \text { TGF- } \beta & \text { Transforming growth factor-beta } \\ \text { TNC } & \text { Tenascin-C } \\ \text { TSP } & \text { Thrombospondin } \\ \text { uPA } & \text { Urokinase-type plasminogen activator } \\ \text { VEGF } & \text { Vascular endothelial growth factor }\end{array}$

\section{References}

1. Uede, T. Osteopontin, intrinsic tissue regulator of intractable inflammatory diseases. Pathol. Int. 2011, 61, 265-280. [CrossRef] [PubMed]

2. Pascapurnama, D.N.; Labayo, H.K.; Dapat, I.; Nagarajegowda, D.D.; Zhao, J.; Zhang, J.; Yamada, O.; Kikuchi, H.; Egawa, S.; Oshima, Y.; et al. Induction of Osteopontin by Dengue Virus-3 Infection in THP-1 Cells: Inhibition of the Synthesis by Brefelamide and Its Derivative. Front. Microbiol. 2017, 8, 521. [CrossRef] [PubMed]

3. Schäfer, G.; Blumenthal, M.J.; Katz, A.A. Interaction of human tumor viruses with host cell surface receptors and cell entry. Viruses 2015, 7, 2592-2617. [CrossRef] [PubMed]

4. Hao, C.; Cui, Y.; Owen, S.; Li, W.; Cheng, S.; Jiang, W.G. Human osteopontin: Potential clinical applications in cancer (Review). Int. J. Mol. Med. 2017, 39, 1327-1337. [CrossRef] [PubMed]

5. Senger, D.; Wirth, D.F.; Hynes, R.O. Transformed mammalian cells secrete specific proteins and phosphoproteins. Cell 1979, 16, 885-893. [CrossRef]

6. Briones-Orta, M.A.; Avendaño-Vázquez, S.E.; Aparicio-Bautista, D.I.; Coombes, J.D.; Weber, G.F.; Syn, W.K. Osteopontin splice variants and polymorphisms in cancer progression and prognosis. Biochim. Biophys. Acta 2017, 1868, 93-108. [CrossRef] [PubMed]

7. Raab-Westphal, S.; Marshall, J.F.; Goodman, S.L. Integrins as Therapeutic Tartes: Success and Cancers. Cancers 2017, 9, 110. [CrossRef] [PubMed]

8. Senbanjo, L.T.; Chellaiah, M.A. CD44: A Multifunctional Cell Surface Adhesion Receptor Is a Regulator of Progression and Metastasis of Cancer Cells. Front. Cell Dev. Biol. 2017, 5, 18. [CrossRef] [PubMed]

9. Wei, R.; Wong, J.P.C.; Kwok, H.F. Osteopontin-A promising biomarker for cancer therapy. J. Cancer 2017, 8, 2173-2183. [CrossRef] [PubMed]

10. Cappellano, G.; Orilieri, E.; Woldetsadik, A.D.; Boggio, E.; Soluri, M.F.; Comi, C.; Sblattero, D.; Chiocchetti, A.; Dianzani, U. Anti-cytokine autoantibodies in autoimmune diseases. Am. J. Clin. Exp. Immunol. 2012, 1, 136-146. [PubMed]

11. Ying, X.; Zhao, Y.; Wang, J.L.; Zhou, X.; Zhao, J.; He, C.C.; Guo, X.J.; Jin, G.H.; Wang, L.J.; Zhu, Q.; et al. Serum anti-osteopontin autoantibody as a novel diagnostic and prognostic biomarker in patients with hepatocellular carcinoma. Oncol. Rep. 2014, 32, 1550-1556. [CrossRef] [PubMed]

12. Dai, J.; Li, B.; Shi, J.; Peng, L.; Zhang, D.; Qian, W.; Hou, S.; Zhao, L.; Gao, J.; Cao, Z.; et al. A humanized anti-osteopontin antibody inhibits breast cancer growth and metastasis in vivo. Cancer Immunol. Immunother. 2010, 59, 355-366. [CrossRef] [PubMed] 
13. Shojaei, F.; Scott, N.; Kang, X.; Lappin, P.B.; Fitzgerald, A.A.; Karlicek, S.; Simmons, B.H.; Wu, A.; Lee, J.H.; Bergqvist, S.; et al. Osteopontin induces growth of metastatic tumors in a preclinical model of non-small lung cancer. J. Exp. Clin. Cancer Res. 2012, 31, 26. [CrossRef] [PubMed]

14. Zhang, B.; Dai, J.; Wang, H.; Wei, H.; Zhao, J.; Guo, Y.; Fan, K. Anti-osteopontin monoclonal antibody prevents ovariectomy-induced osteoporosis in mice by promotion of osteoclast apoptosis. Biochem. Biophys. Res. Commun. 2014, 452, 795-800. [CrossRef] [PubMed]

15. Cen, C.; Aziz, M.; Yang, W.L.; Nicastro, J.M.; Coppa, G.F.; Wang, P. Osteopontin Blockade Attenuates Renal Injury after Ischemia Reperfusion by Inhibiting NK Cell Infiltration. Shock 2017, 47, 52-60. [CrossRef] [PubMed]

16. Chiovaro, F.; Chiquet-Ehrismann, R.; Chiquet, M. Transcriptional regulation of tenascin genes. Cell Adh. Migr. 2015, 9, 34-47. [CrossRef] [PubMed]

17. Midwood, K.S.; Chiquet, M.; Tucker, R.P.; Orend, G. Tenascin-C at a glance. J. Cell Sci. 2016, 129, $4321-4327$. [CrossRef] [PubMed]

18. Tucker, R.P.; Chiquet-Ehrismann, R. Tenascin-C: Its functions as an integrin ligand. Int. J. Biochem. Cell Biol. 2015, 65, 165-168. [CrossRef] [PubMed]

19. Chiquet-Ehrismann, R.; Tucker, R.P. Tenascins and the importance of adhesion modulation. Cold Spring Harb. Perspect. Biol. 2011, 3, a004960. [CrossRef] [PubMed]

20. Imanaka-Yoshida, K.; Aoki, H. Tenascin-C and mechanotrasnduction in the development and diseases of cardiovascular system. Front. Physiol. 2014, 5, 283. [CrossRef] [PubMed]

21. Yoshida, T.; Akatsuka, T.; Imanaka-Yoshida, K. Tenascin-C and integrins in cancer. Cell Adh. Migr. 2015, 9, 96-104. [CrossRef] [PubMed]

22. Schumann, C.; Lepper, P.M.; Frank, H.; Schneiderbauer, R.; Wibmer, T.; Kropf, C.; Stoiber, K.M.; Rüdiger, S.; Kruska, L.; Krahn, T.; et al. Circulating biomarkers of tissue remodelling in pulmonary hypertension. Biomarkers 2010, 15, 523-532. [CrossRef] [PubMed]

23. Page, T.H.; Charles, P.J.; Piccinini, A.M.; Nicolaidou, V.; Taylor, P.C.; Midwood, K.S. Raised circulating tenascin-C in rheumatoid arthritis. Arthritis Res. Ther. 2012, 14, R260. [CrossRef] [PubMed]

24. Balasenthil, S.; Huang, Y.; Liu, S.; Marsh, T.; Chen, J.; Stass, S.A.; KuKuruga, D.; Brand, R.; Chen, N.; Frazier, M.L.; et al. A Plasma Biomarker Panel to Identify Surgically Resectable Early-Stage Pancreatic Cancer. J. Natl. Cancer Inst. 2017, 109. [CrossRef] [PubMed]

25. Mock, A.; Warta, R.; Geisenberger, C.; Bischoff, R.; Schulte, A.; Lamszus, K.; Stadler, V.; Felgenhauer, T.; Schichor, C.; Schwartz, C.; et al. Printed peptide arrays identify prognostic TNC serumantibodies in glioblastoma patients. Oncotarget 2015, 6, 13579-13590. [CrossRef] [PubMed]

26. Odaka, K.; Uehara, T.; Arano, Y.; Adachi, S.; Tadokoro, H.; Yoshida, K.; Hasegawa, H.; Imanaka-Yoshida, K.; Yoshida, T.; Hiroe, M.; et al. Noninvasive detection of cardiac repair after acute myocardial infarction in rats by ${ }^{111}$ In Fab fragment of monoclonal antibody specific for tenascin-C. Int. Heart J. 2008, 49, 481-492. [CrossRef] [PubMed]

27. Kobayashi, N.; Odaka, K.; Uehara, T.; Imanaka-Yoshida, K.; Kato, Y.; Oyama, H.; Tadokoro, H.; Akizawa, H.; Tanada, S.; Hiroe, M.; et al. Toward in vivo imaging of heart disease using a radiolabeled single-chain Fv fragment targeting tenascin-C. Anal. Chem. 2011, 83, 9123-9130. [CrossRef] [PubMed]

28. Kirk, J.A.; Cingolani, O.H. Thrombospondins in the transition from myocardial infarction to heart failure. J. Mol. Cell. Cardiol. 2016, 90, 102-110. [CrossRef] [PubMed]

29. Lawler, J.W.; Slayter, H.S.; Coligan, J.E. Isolation and characterization of a high molecular weight glycoprotein from human blood platelets. J. Biol. Chem. 1978, 253, 8609-8616. [PubMed]

30. Chen, H.; Herndon, M.E.; Lawler, J. The cell biology of thrombospondin-1. Matrix Biol. 2000, 19, 597-614. [CrossRef]

31. Lawler, P.R.; Lawler, J. Molecular basis for the regulation of angiogenesis by thrombospondin-1 and -2 . Cold Spring Harb. Perspect. Med. 2012, 2, a006627. [CrossRef] [PubMed]

32. Dudek, A.Z.; Mahaseth, H. Circulating angiogenic cytokines in patients with advanced non-small cell lung cancer: Correlation with treatment response and survival. Cancer Investig. 2005, 23, 193-200. [CrossRef]

33. Cymbaluk-Płoska, A.; Chudecka-Głaz, A.; Pius-Sadowska, E.; Machaliński, B.; Menkiszak, J. Thrombospondin-I concentrations behavior in plasma of patients with ovarian cancer. Cancer Biomark. 2017, 20, 31-39. [CrossRef] [PubMed] 
34. Kashihara, H.; Shimada, M.; Yoshikawa, K.; Higashijima, J.; Tokunaga, T.; Nishi, M.; Takasu, C.; Ishikawa, D. Correlation Between Thrombospondin-1 Expression in Non-cancer Tissue and Gastric Carcinogenesis. Anticancer Res. 2017, 37, 3547-3552. [PubMed]

35. Jeanne, A.; Schneider, C.; Martiny, L.; Dedieu, S. Original insights on thrombospondin-1-related antireceptor strategies in cancer. Front. Pharmacol. 2015, 6, 252. [CrossRef] [PubMed]

36. Coronella, J.; Li, L.; Johnson, K.; Pirie-Shepherd, S.; Roxas, G.; Levin, N. Selective activity against proliferating tumor endothelial cells by CVX-22, a thrombospondin-1 mimetic CovX-Body. Anticancer Res. 2009, 29, 2243-2252. [PubMed]

37. Li, L.; Leedom, T.A.; Do, J.; Huang, H.; Lai, J.; Johnson, K.; Osothprarop, T.F.; Rizzo, J.D.; Doppalapudi, V.R.; Bradshaw, C.W.; et al. Antitumor efficacy of a thrombospondin 1 mimetic CovX-body. Transl. Oncol. 2011, 4, 249-257. [CrossRef] [PubMed]

38. Takeshita, S.; Kikuno, R.; Tezuka, K.; Amann, E. Osteoblast-specific factor 2: Cloning of a putative bone adhesion protein with homology with the insect protein fasciclin I. Biochem. J. 1993, 294, 271-278. [CrossRef] [PubMed]

39. Idolazzi, L.; Ridolo, E.; Fassio, A.; Gatti, D.; Montagni, M.; Caminati, M.; Martignago, I.; Incorvaia, C.; Senna, G. Periostin: The bone and beyond. Eur. J. Intern. Med. 2017, 38, 12-16. [CrossRef] [PubMed]

40. Nuzzo, P.V.; Buzzatti, G.; Ricci, F.; Rubagotti, A.; Argellati, F.; Zinoli, L.; Boccardo, F. Periostin: A novel prognostic and therapeutic target for genitourinary cancer? Clin. Genitourin. Cancer 2014, 12, 301-311. [CrossRef] [PubMed]

41. Gillan, L.; Matei, D.; Fishman, D.A.; Gerbin, C.S.; Karlan, B.Y.; Chang, D.D. Periostin secreted by epithelial ovarian carcinoma is a ligand for $\alpha_{\mathrm{v}} \beta_{3}$ and $\alpha_{\mathrm{v}} \beta_{5}$ integrins and promotes cell motility. Cancer Res. 2002, 62, 5358-5364. [PubMed]

42. Baril, P.; Gangeswaran, R.; Mahon, P.C.; Caulee, K.; Kocher, H.M.; Harada, T.; Zhu, M.; Kalthoff, H.; Crnogorac-Jurcevic, T.; Lemoine, N.R. Periostin promotes invasiveness and resistance of pancreatic cancer cells to hypoxia-induced cell death: Role of the $\beta_{4}$ integrin and the PI3k pathway. Oncogene 2007, 26, 2082-2094. [CrossRef] [PubMed]

43. Moniuszko, T.; Wincewicz, A.; Koda, M.; Domysławska, I.; Sulkowski, S. Role of periostin in esophageal, gastric and colon cancer. Oncol. Lett. 2016, 12, 783-787. [CrossRef] [PubMed]

44. Liu, Y.; Liu, B.A. Enhanced proliferation, invasion, and epithelial-mesenchymal transition of nicotine-promoted gastric cancer by periostin. World J. Gastroenterol. 2011, 17, 2674-2680. [CrossRef] [PubMed]

45. Nuzzo, P.V.; Rubagotti, A.; Argellati, F.; Di Meglio, A.; Zanardi, E.; Zinoli, L.; Comite, P.; Mussap, M.; Boccardo, F. Prognostic Value of Preoperative Serum Levels of Periostin (PN) in Early Breast Cancer (BCa). Int. J. Mol. Sci. 2015, 16, 17181-17192. [CrossRef] [PubMed]

46. Thuwajit, C.; Thuwajit, P.; Jamjantra, P.; Pairojkul, C.; Wongkham, S.; Bhudhisawasdi, V.; Ono, J.; Ohta, S.; Fujimoto, K.; Izuhara, K. Clustering of patients with intrahepatic cholangiocarcinoma based on serum periostin may be predictive of prognosis. Oncol. Lett. 2017, 14, 623-634. [CrossRef] [PubMed]

47. Xu, C.H.; Wang, W.; Lin, Y.; Qian, L.H.; Zhang, X.W.; Wang, Q.B.; Yu, L.K. Diagnostic and prognostic value of serum periostin in patients with non-small cell lung cancer. Oncotarget 2017, 8, 18746-18753. [CrossRef] [PubMed]

48. Field, S.; Uyttenhove, C.; Stroobant, V.; Cheou, P.; Donckers, D.; Coutelier, J.P.; Simpson, P.T.; Cummings, M.C.; Saunus, J.M.; Reid, L.E.; et al. Novel highly specific anti-periostin antibodies uncover the functional importance of the fascilin 1-1 domain and highlight preferential expression of periostin in aggressive breast cancer. Int. J. Cancer 2016, 138, 1959-1970. [CrossRef] [PubMed]

49. Kyutoku, M.; Taniyama, Y.; Katsuragi, N.; Shimizu, H.; Kunugiza, Y.; Iekushi, K.; Koibuchi, N.; Sanada, F.; Oshita, Y.; Morishita, R. Role of periostin in cancer progression and metastasis: Inhibition of breast cancer progression and metastasis by anti-periostin antibody in a murine model. Int. J. Mol. Med. 2011, 28, 181-186. [CrossRef] [PubMed]

50. Termine, J.D.; Kleinman, H.K.; Whitson, S.W.; Conn, K.M.; McGarvey, M.L.; Martin, G.R. Osteonectin, a bone-specific protein linking mineral to collagen. Cell 1981, 26, 99-105. [CrossRef]

51. Said, N. Roles of SPARC in urothelial carcinogenesis, progression and metastasis. Oncotarget 2016, 7, 67574-67585. [CrossRef] [PubMed] 
52. Trombetta-Esilva, J.; Bradshaw, A.D. The Function of SPARC as a Mediator of Fibrosis. Open Rheumatol. J. 2012, 6, 146-155. [CrossRef] [PubMed]

53. Said, N.; Frierson, H.F.; Sanchez-Carbayo, M.; Brekken, R.A.; Theodorescu, D. Ross of SPARC in bladder cancer enhances carcinogenesis and progression. J. Clin. Investig. 2013, 123, 751-766. [CrossRef] [PubMed]

54. Shi, D.; Jiang, K.; Fu, Y.; Fang, R.; Liu, X.I.; Chen, J. Overexpression of SPARC correlates with poor prognosis in patients with cervical carcinoma and regulates cancer cell epithelial-mesenchymal transition. Oncol. Lett. 2016, 11, 3251-3258. [CrossRef] [PubMed]

55. Vaz, J.; Ansari, D.; Sasor, A.; Andersson, R. SPARC: A Potential Prognostic and Therapeutic Target in Pancreatic Cancer. Pancreas 2015, 44, 1024-1035. [CrossRef] [PubMed]

56. Mateo, F.; Meca-Cortés, O.; Celià-Terrassa, T.; Fernández, Y.; Abasolo, I.; Sánchez-Cid, L.; Bermudo, R.; Sagasta, A.; Rodríguez-Carunchio, L.; Pons, M.; et al. SPARC mediates metastatic cooperation between CSC and non-CSC prostate cancer cell subpopulations. Mol. Cancer 2014, 13, 237. [CrossRef] [PubMed]

57. Grant, J.L.; Fishbein, M.C.; Hong, L.S.; Krysan, K.; Minna, J.D.; Shay, J.W.; Walser, T.C.; Dubinett, S.M. A novel molecular pathway for Snail-dependent, SPARC-mediated invasion in non-small cell lung cancer pathogenesis. Cancer Prev. Res. 2014, 7, 150-160. [CrossRef] [PubMed]

58. Chiodoni, C.; Sangaletti, S.; Colombo, M.P. Matricellular proteins tune myeloid-derived suppressor Cell recruitment and function in breast cancer. J. Leukoc. Biol. 2017, 102, 287-292. [CrossRef] [PubMed]

59. Maeda, N.; Fan, H.; Yoshikai, Y. Oncogenesis by retroviruses: Old and new paradigms. Rev. Med. Virol. 2008, 18, 387-405. [CrossRef] [PubMed]

60. Katsuya, H.; Ishitsuka, K. Treatment advances and prognosis for patients with adult T-cell leukemia-lymphoma. J. Clin. Exp. Hematop. 2017, 17008. [CrossRef] [PubMed]

61. Watanabe, T. Adult T-cell leukemia: Molecular basis for clonal expansion and transformation of HTLV-1-infected T cells. Blood 2017, 129, 1071-1081. [CrossRef] [PubMed]

62. Kogure, Y.; Kataoka, K. Genetic alterlations in adult T-cell leukemia/lymphoma. Cancer Sci. 2017. [CrossRef] [PubMed]

63. Zhang, J.; Yamada, O.; Matsushita, Y.; Chagan-Yasutan, H.; Hattori, T. Transactivation of human osteopontin promoter by human T-cell leukemia virus type 1-encoded Tax protein. Leuk. Res. 2010, 34, 763-768. [CrossRef] [PubMed]

64. Maeda, N.; Ohashi, T.; Chagan-Yasutan, H.; Hattori, T.; Takahashi, Y.; Harigae, H.; Hasegawa, H.; Yamada, Y.; Fujii, M.; Maenaka, K.; et al. Osteopontin-integrin interaction as a novel molecular target for antibody-mediated immunotherapy in adult T-cell leukemia. Retrovirology 2015, 12, 99. [CrossRef] [PubMed]

65. Chagan-Yasutan, H.; Tsukasaki, K.; Takahashi, Y.; Oguma, S.; Harigae, H.; Ishii, N.; Zhang, J.; Fukumoto, M.; Hattori, T. Involvement of osteopontin and its signaling molecule CD44 in clinicopathological features of adult T cell leukemia. Leuk. Res. 2011, 35, 1484-1490. [CrossRef] [PubMed]

66. Dai, J.; Peng, L.; Fan, K.; Wang, H.; Wei, R.; Ji, G.; Cai, J.; Lu, B.; Li, B.; Zhang, D.; et al. Osteopontin induces angiogenesis through activation of PI3K/AKT and ERK1/2 in endothelial cells. Oncogene 2009, 28, 3412-3422. [CrossRef] [PubMed]

67. Chakraborty, G.; Jain, S.; Kundu, G.C. Osteopontin promotes vascular endothelial growth factor-dependent breast tumor growth and angiogenesis via autocrine and paracrine mechanisms. Cancer Res. 2008, 68, 152-161. [CrossRef] [PubMed]

68. El-Sabban, M.E.; Merhi, R.A.; Haidar, H.A.; Arnulf, B.; Khoury, H.; Basbous, J.; Nijmeh, J.; de Thé, H.; Hermine, O.; Bazarbachi, A. Human T-cell lymphotropic virus type 1-transformed cells induce angiogenesis and establish functional gap junctions with endothelial cells. Blood 2002, 99, 3383-3389. [CrossRef] [PubMed]

69. Bazarbachi, A.; Abou Merhi, R.; Gessain, A.; Talhouk, R.; El-Khoury, H.; Nasr, R.; Gout, O.; Sulahian, R.; Homaidan, F.; de Thé, H.; et al. Human T-cell lymphotropic virus type I-infected cells extravasate through the endothelial barrier by a local angiogenesis-like mechanism. Cancer Res. 2004, 64, 2039-2046. [CrossRef] [PubMed]

70. Watters, K.M.; Dean, J.; Gautier, V.; Hall, W.W.; Sheehy, N. Tax 1-independent induction of vascular endothelial growth factor in adult T-cell leukemia caused by human T-cell leukemia virus type 1. J. Virol. 2010, 84, 5222-5228. [CrossRef] [PubMed] 
71. Ohyashiki, J.H.; Hamamura, R.; Kobayashi, C.; Zhang, Y.; Ohyashiki, K. A network biology approach evaluating the anticancer effects of bortezomib identifies SPARC as a therapeutic target in adult T-cell leukemia cells. Adv. Appl. Bioinform. Chem. 2008, 1, 85-98. [CrossRef] [PubMed]

72. Liu, S.; Koh, S.S.; Lee, C.G. Hepatitis B Virus X Protein and Hepatocarcinogenesis. Int. J. Mol. Sci. 2016, 17, 940. [CrossRef] [PubMed]

73. Xu, W.; Yu, J.; Wong, V.W. Mechanism and prediction of HCC development in HBV infection. Best Pract. Res. Clin. Gastroenterol. 2017, 31, 291-298. [CrossRef] [PubMed]

74. Zhang, X.; Ye, L.H.; Zhang, X.D. A mutant of hepatitis B virus X protein (HBx $\Delta 127)$ enhances hepatoma cell migration via osteopontin involving 5-lipoxygenase. Acta Pharmacol. Sin. 2010, 31, 593-600. [CrossRef] [PubMed]

75. Zhang, X.; You, X.; Wang, Q.; Zhang, T.; Du, Y.; Lv, N.; Zhang, Z.; Zhang, S.; Shan, C.; Ye, L.; et al. Hepatitis $B$ virus $X$ protein drives multiple cross-talk cascade loops involving NF-kB, 5-LOX, OPN and Capn4 to promote cell migration. PLoS ONE 2012, 7, e31458. [CrossRef] [PubMed]

76. Zhao, L.; Li, T.; Wang, Y.; Pan, Y.; Ning, H.; Hui, X.; Xie, H.; Wang, J.; Han, Y.; Liu, Z.; et al. Elevated plasma osteopontin level is predictive of cirrhosis in patients with hepatitis B infection. Int. J. Clin. Pract. 2008, 62, 1056-1062. [CrossRef] [PubMed]

77. Da Costa, A.N.; Plymoth, A.; Santos-Silva, D.; Ortiz-Cuaran, S.; Camey, S.; Guilloreau, P.; Sangrajrang, S.; Khuhaprema, T.; Mendy, M.; Lesi, O.A.; et al. Osteopontin and latent-TGF $\beta$ binding-protein 2 as potential diagnostic markers for HBV-related hepatocellular carcinoma. Int. J. Cancer 2015, 136, 172-181. [CrossRef] [PubMed]

78. Xie, H.; Song, J.; Du, R.; Liu, K.; Wang, J.; Tang, H.; Bai, F.; Liang, J.; Lin, T.; Liu, J.; et al. Prognostic significance of osteopontin in hepatitis B virus-related hepatocellular carcinoma. Dig. Liver Dis. 2007, 39, 167-172. [CrossRef] [PubMed]

79. Cui, G.; Chen, J.; He, J.; Lu, C.; Wei, Y.; Wang, L.; Xu, X.; Li, L.; Uede, T.; Diao, H. Osteopontin promotes dendritic cell maturation and function in response to HBV antigens. Drug Des. Dev. Ther. 2015, 9, 3003-3016. [CrossRef]

80. Zhang, B.; Wang, Z.; Deng, B.; Wu, X.; Liu, J.; Feng, X. Identification of Enolase 1 and Thrombospondin-1 as serum biomarkers in HBV hepatic fibrosis by proteomics. Proteome Sci. 2013, 11, 30. [CrossRef] [PubMed]

81. Bastos, J.C.; Padilla, M.A.; Caserta, L.C.; Miotto, N.; Vigami, A.G.; Arns, C.W. Hepatitis C virus: Promising discoveries and new treatments. World J. Gastroenterol. 2016, 22, 6393-6401. [CrossRef] [PubMed]

82. Vescovo, T.; Refolo, G.; Vitagliano, G.; Fimia, G.M.; Piacentini, M. Molecular mechanisms of hepatitis C virus-induced hepatocellular carcinoma. Clin. Microbiol. Infect. 2016, 22, 853-861. [CrossRef] [PubMed]

83. Presser, L.D.; Haskett, A.; Waris, G. Hepatitis C virus-induced furin and thrombospondin- 1 activate TGF- $\beta 1$ : Role of TGF- $\beta 1$ in HCV replication. Virology 2011, 412, 284-296. [CrossRef] [PubMed]

84. Benzoubir, N.; Lejamtel, C.; Battaglia, S.; Testoni, B.; Benassi, B.; Gondeau, C.; Perrin-Cocon, L.; Desterke, C.; Thiers, V.; Samuel, D.; et al. HCV core-mediated activation of latent TGF- $\beta$ via thrombospondin drives the crosstalk between hepatocytes and stromal environment. J. Hepatol. 2013, 59, 1160-1168. [CrossRef] [PubMed]

85. Bose, S.K.; Meyer, K.; Di Bisceglie, A.M.; Ray, R.B.; Ray, R. Hepatitis C virus induces epithelial-mesenchymal transition in primary human hepatocytes. J. Virol. 2012, 86, 13621-13628. [CrossRef] [PubMed]

86. Kwon, Y.C.; Bose, S.K.; Steele, R.; Meyer, K.; Di Bisceglie, A.M.; Ray, R.B.; Ray, R. Promotion of Cancer Stem-Like Cell Properties in Hepatitis C Virus-Infected Hepatocytes. J. Virol. 2015, 89, 11549-11556. [CrossRef] [PubMed]

87. Sasaki, R.; Devhare, P.; Ray, R.B.; Ray, R. Hepatitis C virus induced tumor initiating cancer stem-like cells activate stromal fibroblasts in xenograft tumor model. Hepatology 2017. [CrossRef] [PubMed]

88. Huang, W.; Zhu, G.; Huang, M.; Lou, G.; Liu, Y.; Wang, S. Plasma osteopontin concentration correlates with the severity of hepatic fibrosis and inflammation in HCV-infected subjects. Clin. Chim. Acta 2010, 411, 675-678. [CrossRef] [PubMed]

89. Abu El Makarem, M.A.; Abdel-Aleem, A.; Ali, A.; Saber, R.; Shatat, M.; Rahem, D.A.; Sayed, D. Diagnostic significance of plasma osteopontin in hepatitis C virus-related hepatocellular carcinoma. Ann. Hepatol. 2011, 10, 296-305. [PubMed] 
90. Matsue, Y.; Tsutsumi, M.; Hayashi, N.; Saito, T.; Tsuchishima, M.; Toshikuni, N.; Arisawa, T.; George, J. Serum osteopontin predicts degree of hepatic fibrosis and serves as a biomarker in patients with hepatitis C virus infection. PLOS ONE 2015, 10, e0118744. [CrossRef] [PubMed]

91. Cabiati, M.; Gaggini, M.; Cesare, M.M.; Caselli, C.; De Simone, P.; Filipponi, F.; Basta, G.; Gastaldelli, A.; Del Ry, S. Osteopontin in hepatocellular carcinoma: A possible biomarker for diagnosis and follow-up. Cytokine 2017, 99, 59-65. [CrossRef] [PubMed]

92. Chen, R.X.; Xia, Y.H.; Xue, T.C.; Zhang, H.; Ye, S.L. Down-regulation of osteopontin inhibits metastasis of hepatocellular carcinoma cells via a mechanism involving MMP-2 and uPA. Oncol. Rep. 2011, 25, 803-808. [CrossRef] [PubMed]

93. Iqbal, J.; McRae, S.; Banaudha, K.; Mai, T.; Waris, G. Mechanism of hepatitis C virus (HCV)-induced osteopontin and its role in epithelial to mesenchymal transition of hepatocytes. J. Biol. Chem. 2013, 288, 36994-37009. [CrossRef] [PubMed]

94. Shanmugasundaram, S.; You, J. Targeting Persistent Human Papillomavirus Infection. Viruses 2017, 9, 229. [CrossRef]

95. Senapati, R.; Senapati, N.N.; Dwibedi, B. Molecular mechanisms of HPV mediated neoplastic progression. Infect. Agent. Cancer 2016, 11, 59. [CrossRef] [PubMed]

96. Bequet-Romero, M.; López-Ocejo, O. Angiogenesis modulators expression in culture cell lines positives for HPV-16 oncoproteins. Biochem. Biophys. Res. Commun. 2000, 277, 55-61. [CrossRef] [PubMed]

97. Toussaint-Smith, E.; Donner, D.B.; Roman, A. Expression of human papillomavirus type 16 E6 and E7 oncoproteins in primary foreskin keratinocytes is sufficient to alter the expression of angiogenic factors. Oncogene 2004, 23, 2988-2995. [CrossRef] [PubMed]

98. Chen, W.; Li, F.; Mead, L.; White, H.; Walker, J.; Ingram, D.A.; Roman, A. Human papillomavirus causes an angiogenic switch in keratinocytes which is sufficient to alter endothelial cell behavior. Virology 2007, 367, 168-174. [CrossRef] [PubMed]

99. Bao, L.; Si, Q.; Jia, L.; Ren, X.; Ma, R.; Wang, Y. Detection of human papillomavirus and expression of osteopontin in cervical cancer specimens. Mol. Med. Rep. 2015, 11, 447-453. [CrossRef] [PubMed]

100. Richards, R.M.; Lowy, D.R.; Schiller, J.T.; Day, P.M. Cleavage of the papillomavirus minor capsid protein, L2, at a furin consensus site is necessary for infection. Proc. Natl. Acad. Sci. USA 2006, 103, 1522-1527. [CrossRef] [PubMed]

101. Kumar, V.; Behera, R.; Lohite, K.; Karnik, S.; Kundu, G.C. p38 kinase is crucial for osteopontin-induced furin expression that supports cervical cancer progression. Cancer Res. 2010, 70, 10381-10391. [CrossRef] [PubMed]

102. Tiitta, O.; Wahlström, T.; Paavonen, J.; Linnala, A.; Sharma, S.; Gould, V.E.; Virtanen, I. Enhanced tenascin expression in cervical and vulvar koilocytotic lesions. Am. J. Pathol. 1992, 141, 907-913. [PubMed]

103. Pöllänen, R.; Soini, Y.; Vuopala, S.; Läärä, E.; Lehto, V.P. Tenascin in human papillomavirus associated lesions of the uterine cervix. J. Clin. Pathol. 1996, 49, 521-523. [CrossRef] [PubMed]

104. Spurgeon, M.E.; Lambert, P.F. Human Papillomavirus and the Stroma: Bidirectional Crosstalk during the Virus Life Cycle and Carcinogenesis. Viruses 2017, 9, 219. [CrossRef] [PubMed]

105. Ali, A.S.; Al-Shraim, M.; Al-Hakami, A.M.; Jones, I.M. Epstein-Barr Virus: Clinical and Epidemiological Revisits and Genetic Basis of Oncogenesis. Open Virol. J. 2015, 9, 7-28. [CrossRef] [PubMed]

106. Jha, H.C.; Pei, Y.; Robertson, E.S. Epstein-Barr Virus: Diseases Linked to Infection and Transformation. Front. Microbiol. 2016, 7, 1602. [CrossRef] [PubMed]

107. Tang, W.; Morgan, D.R.; Meyers, M.O.; Dominguez, R.L.; Martinez, E.; Kakudo, K.; Kuan, P.F.; Banet, N.; Muallem, H.; Woodward, K.; et al. Epstein-Barr virus infected gastric adenocarcinoma expresses latent and lytic viral transcripts and has a distinct human gene expression profile. Infect. Agent. Cancer 2012, 7, 21. [CrossRef] [PubMed]

108. Luo, W.; Yao, K. Molecular characterization and clinical implications of spindle cells in nasopharyngeal carcinoma: A novel molecule-morphology model of tumor progression proposed. PLoS ONE 2013, 8, e83135. [CrossRef] [PubMed]

109. Aneja, K.K.; Yuan, Y. Reactivation and Lytic Replication of Kaposi's Sarcoma-Associated Herpesvirus: An Update. Front. Microbiol. 2017, 8, 613. [CrossRef] [PubMed]

110. Dittmer, D.P.; Damania, B. Kaposi's sarcoma-associated herpesvirus: Immunobiology, oncogenesis, and therapy. J. Clin. Investig. 2016, 126, 3165-3175. [CrossRef] [PubMed] 
111. Kang, S.; Myoung, J. Primary lymphocyte infection models for KSHV and its putative tumorigenesis mechanisms in B cell lymphomas. J. Microbiol. 2017, 55, 319-329. [CrossRef] [PubMed]

112. Kaaya, E.E.; Castaños-Velez, E.; Amir, H.; Lema, L.; Luande, J.; Kitinya, J.; Patarroyo, M.; Biberfeld, P. Expression of adhesion molecules in endemic and epidemic Kaposi's sarcoma. Histopathology 1996, 29, 337-346. [CrossRef] [PubMed]

113. Taraboletti, G.; Benelli, R.; Borsotti, P.; Rusnati, M.; Presta, M.; Giavazzi, R.; Ruco, L.; Albini, A. Thrombospondin-1 inhibits Kaposi's sarcoma (KS) cell and HIV-1 Tat-induced angiogenesis and is poorly expressed in KS lesions. J. Pathol. 1999, 188, 76-81. [CrossRef]

114. Samols, M.A.; Skalsky, R.L.; Maldonado, A.M.; Riva, A.; Lopez, M.C.; Baker, H.V.; Renee, R. Identification of cellular genes targeted by KSHV-encoded microRNAs. PLoS Pathog. 2007, 3, e65. [CrossRef] [PubMed]

115. Cao, Y.; Qiao, J.; Lin, Z.; Zabaleta, J.; Dai, L.; Qin, Z. Up-regulation of tumor suppressor genes by exogenous dhC16-Cer contributes to its anti-cancer activity in primary effusion lymphoma. Oncotarget 2017, 8, 15220-15229. [CrossRef] [PubMed]

116. Feng, H.; Shuda, M.; Chang, Y.; Moore, P.S. Clonal integration of a polyomavirus in human Merkel cell carcinoma. Science 2008, 319, 1096-1100. [CrossRef] [PubMed]

117. Liu, W.; MacDonald, M.; You, J. Merkel cell polyomavirus infection and Merkel cell carcinoma. Curr. Opin. Virol. 2016, 20, 20-27. [CrossRef] [PubMed]

118. Koljonen, V.; Jahkola, T.; Tukiainen, E.; Granroth, G.; Haglund, C.; Böhling, T. Tenascin-C in primary Merkel cell carcinoma. J. Clin. Pathol. 2005, 58, 297-300. [CrossRef] [PubMed]

119. Koljonen, V.; Böhling, T.; Tukiainen, E.; Haglund, C.; Jahkola, T. Tenascin-C expression in Merkel cell carcinoma lymph node metastasis. APMIS 2006, 114, 39-42. [CrossRef] [PubMed]

120. Liu, W.; Yang, R.; Payne, A.S.; Schowalter, R.M.; Spurgeon, M.E.; Lambert, P.F.; Xu, X.; Buck, C.B.; You, J. Identifying the Target Cells and Mechanisms of Merkel Cell Polyomavirus Infection. Cell Host Microbe 2016, 19, 775-787. [CrossRef] [PubMed]

121. Shuda, M.; Kwun, H.J.; Feng, H.; Chang, Y.; Moore, P.S. Human Merkel cell polyomavirus small T antigen is an oncoprotein targeting the 4E-BP1 translation regulator. J. Clin. Investig. 2011, 121, 3623-3634. [CrossRef] [PubMed]

122. Maeda, N.; Matsuda, A.; Maenaka, K. Antibody-mediated molecular-targeted therapy for adult T-cell leukemia: Recent progress and future challenges in the treatment of cancers. Cancer Cell Microenviron. 2016, 3, e1201. [CrossRef] 